\title{
Synaptically Released Histamine Increases Dye Coupling among Vasopressinergic Neurons of the Supraoptic Nucleus: Mediation by $\mathrm{H}_{1}$ Receptors and Cyclic Nucleotides
}

\author{
G. I. Hatton and Q. Z. Yang \\ Department of Neuroscience, University of California, Riverside, California 92521
}

Activating direct olfactory (glutamatergic) inputs to supraoptic nucleus (SON) neurons increases interneuronal coupling in slices from lactating but from not virgin or male rats. Studied here were influences on coupling of another monosynaptic input to SON, the histaminergic tuberomammillary nucleus (TM) projection, activation of which selectively excites phasically firing (putative vasopressin) cells. Effects of TM stimulation and its possible downstream consequences on Lucifer yellow (LY) dye coupling among putative vasopressin cells were determined in male rat SONs. In unstimulated slices, $12 \mathrm{LY}$ injections (1 cell/SON) yielded eight single and four pairs of coupled neurons. In slices in which TM was stimulated for $10 \mathrm{~min}$ at 10 $\mathrm{Hz}, 13$ injections yielded 4 single and 28 coupled cells, with groups of 2 to 4 cells coupled to the injected neuron, a threefold increase in the number of coupled cells per injection $(p<0.02)$.
Bathing slices in medium containing $10 \mu \mathrm{M}$ pyrilamine $\left(\mathrm{H}_{1}\right.$ antagonist) blocked this stimulation-induced coupling increase, suggesting mediation by activation of guanylate cyclase-cGMP to which $\mathrm{H}_{1}$ receptors often are linked. Bathing slices in medium containing $0.5-1 \mathrm{~mm}$ 8-bromo-cGMP yielded results similar to those of TM stimulation, a 2.5-fold increase over control in the number of coupled cells per injection. Effects of TM stimulation on coupling also were blocked by bathing slices in a guanylate cyclase inhibitor (10 $\mu \mathrm{M}$ LY83583). In contrast to cGMP, $1 \mathrm{~mm}$ 8-bromo-cAMP significantly reduced coupling. We conclude that synaptically released histamine increases coupling via cGMP-dependent mechanisms.

Key words: CAMP; CGMP; gap junctions; intracellular recording; hypothalamic slices; Lucifer yellow; tuberomammillary nucleus
Coupling via electrical synapses in the mammalian central nervous system (CNS) is one of the more intriguing phenomena to come to light in recent times. Once considered a rare oddity found only in obscure cell groups or in invertebrates, and therefore of no real significance, coupling has now been demonstrated among neurons in brain areas as diverse as the mesencephalic trigeminal nucleus (Baker and Llinas, 1971), inferior olive (Llinas et al., 1974), neocortex (Gutnick and Prince, 1981), hippocampal formation (MacVicar and Dudek, 1981), hypothalamus (Andrew et al., 1981), dentate gyrus (MacVicar and Dudek, 1982), substantia nigra (Grace and Bunney, 1983), lateral septum (Phalen et al., 1993), nucleus accumbens (O'Donnell and Grace, 1993), striatum (Onn and Grace, 1994), locus coeruleus (Travagli et al., 1994) and the retina (see Vaney, 1994), often considered an extension of the CNS. Such coupling no longer can be ignored as a factor that may have profound influences on brain function. Coupling is probably more widespread than is currently appreciated, because it is found almost everywhere that serious attempts are made to look for it. The structures supporting coupling are connexons, intercellular channels consisting of connexin proteins. Clusters of connexons (gap junction plaques) are readily identified at the electron microscopic level, given sufficiently large plaques and proper planes of section, but intercellular communication via connexons is not restricted to those cases (Hatton, 1990; Dermietzel and Spray, 1993; DeZeeuw et al., 1995).

\footnotetext{
Received Aug. 4, 1995; revised Sept. 18, 1995; accepted Sept. 21, 1995.

This rescarch was supported by NIII Rescarch Grants RO1 NS16942 and RO1 NS09140 from the NINDS. We thank Drs. Z. Li and J. Ashe for helpful comments on an earlier draft of the manuscript and J. Kitasako for expert technical assistance.

Correspondence should be addressed to Glenn I. Hatton at the above address.

Copyright (C) 1995 Society for Neuroscience $0270-6474 / 95 / 160123-07 \$ 05.00 / 0$
}

Mammalian brain tissue expresses several connexins, but it is connexin-32, expressed by certain populations of neurons (Nagy et al., 1988; Dermietzel and Spray, 1993), that forms the intercellular channels believed to mediate neuronal dye transfer and electrical coupling. Supraoptic nucleus (SON) neurons express mRNA for connexin-32 (Micevych and Abelson, 1991), and expression levels are low under conditions in which coupling incidence is low and are high under conditions in which the incidence of coupling has been physiologically upregulated (Hatton and Micevych, 1992) (P. E. Micevych, P. Popper, and G. I. Hatton, unpublished observations). Recently, DeZeeuw et al. (1995) showed that SON neurons contained dendritic lamellar bodies, structures associated in several brain regions with dendrodendritic gap junctions and electrotonic coupling.

We sought to determine whether the synaptically enhanced coupling observed previously (Hatton and Yang, 1990; Modney et al., 1990) was peculiar to the special conditions and glutamatergic input studied or whether excitation via a nonglutamatergic pathway also would influence coupling. Furthermore, we sought to ascertain which cellular mechanisms modulate coupling. To these ends, we exploited the monosynaptic connection between the histaminergic tuberomammillary nucleus (TM) and the SON (Inagaki et al., 1988; Panula et al., 1989; Yang and Hatton, 1989, 1994). Selective excitation of vasopressinergic SON neurons is achieved by TM stimulation (Yang and Hatton, 1994), current injection into TM neurons (Yang and Hatton, 1989), or application of histamine (HA) ( $\mathrm{Li}$ and Hatton, 1995). Histaminergic depolarization of vasopressinergic neurons is via $\mathrm{II}_{1}$ receptor subtype activation (Armstrong and Sladek, 1985; Yang and Hatton, 1989; Smith and Armstrong, 1993; Yang and Hatton, 1994; Li and Hatton, 1995). 


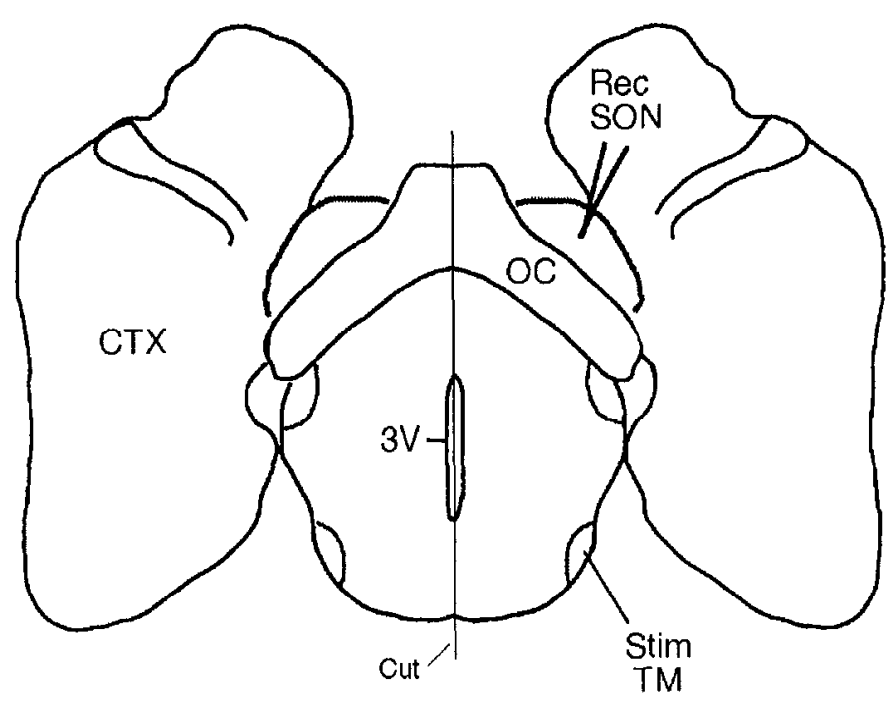

Figure 1. Diagram of horizontally cut slice through the ventral hypothalamus, typical of those used here, which maintains the histaminergic axonal projections from the TM to the SON. Slices were hemisected along the vertical line (Cut). CTX: cortex; OC: optic chiasm; Rec: recording electrode; Stim: stimulating electrode; $3 V$ : third ventricle.

\section{MATERIALS AND METHODS}

Adult malc Spraguc-Dawley rats, 50- to 60-d-old, were housed in group cages ( 3 rats per cage) with ad libitum food and water on a $12 \mathrm{hr}$ light $/ 12$ $\mathrm{hr}$ dark cycle. At $\sim 4-5 \mathrm{hr}$ into the light portion of the cycle, they were gently introduced to a guillotine and decapitated without anesthesia. Brains were quickly removed, mounted cortex-down on the stage of a Vibratome, cut in the horizontal plane at $400-500 \mu \mathrm{m}$, and placed in room temperature medium. Slices were then hemisected along the third ventricle by severing the optic chiasm and the medial mammillary bodies (Fig. 1) and transferred to one of two types of recording chamber, either a ramp style (Haas et al., 1979) or a static bath chamber (Hatton et al., 1980). There they were maintained at $34-35^{\circ} \mathrm{C}$ in medium gassed with 95\% $\mathrm{O}_{2} / 5 \% \mathrm{CO}_{2}$. Medium composition was as follows (in $\mathrm{mM}$ ): $\mathrm{NaCl} 126$, $\mathrm{NaHPO}_{4} 1.3, \mathrm{NaHCO}_{3} 26, \mathrm{KCl} 5, \mathrm{CaCl}_{2} 2.4, \mathrm{MgSO}_{4} 1.3$, glucose 10, and $3[\mathrm{~N}$-morpholino]propanesulfonic acid buffer $5, \mathrm{pH} 7.4$. Recording electrodes wcrc glass micropipettes filled with $3 \%$ Lucifer yellow (LY) CH

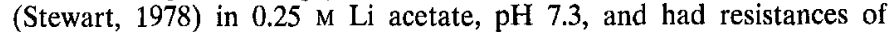
$100-150 \mathrm{M} \Omega$. Extracellular electrical stimulation was delivered through concentric bipolar electrodes (MCE 100, Rhodes Medical Instruments, Woodland Hills, CA) using constant current.

Procedures. As in our previous coupling studies (Andrew et al., 1981; Cobbett and Hatton, 1984; Yang and Hatton, 1988; Hatton and Yang, 1994), the following precautions were taken to prevent spurious coupling: (1) only one neuron per SON was recorded and injected; (2) brief pulses of positive current were used in making impalements; and (3) penetrations were terminated if the action potential amplitude fell below $40 \mathrm{mV}$ during the LY injections. Intracellular impalements were not attempted until after an incubation period of $3 \mathrm{hr}$. LY was injected using pulsed negative currents $(200 \mathrm{msec}$ pulses at -0.1 to $-0.3 \mathrm{nA})$ for $2-3 \mathrm{~min}$. In experiments involving electrical stimulation, an SON neuron was impaled and its response to stimulation of the TM was determined. Only neurons in which TM stimulation evoked excitatory responses were included. These cells were LY-injected and either stimulated for $10 \mathrm{~min}$ at $10 \mathrm{~Hz}$ or, in the case of controls, simply recorded for $10 \mathrm{~min}$ after the LY injection. TM stimulation parameters were $20-100 \mu \mathrm{A}, 0.1 \mathrm{msec}$. In all experiments, half of the slice received the experimental treatment and the other half was subjected to control procedures. In experiments involving manipulation of the medium composition, a cell in one half-slice was LY-injected, and then that half was removed and stored in the same medium until the other half-slice had been treated and injected. Then after a further delay of $\sim 30 \mathrm{~min}$, both halves were placed in buffered $4 \%$ $p$-formaldehyde fixative. In our previous studies, no relationship was found between incidence of coupling and time from LY injection to fixation of the slice. Incidence of dyc coupling was determincd under epiffuorescence on slices that were dehydrated and cleared in methyl salicylate (see Fig. 2). Statistical analyses of coupling incidence were performed using either $\chi^{2}$ or Fisher's exact probability test.

Drugs and other compounds. Compounds and the concentrations at which they were used were as follows: 8-bromo-cAMP, $1 \mathrm{mM}$; 8-bromocGMP, 0.5-1.0 mM; LY83583; 6-anilinoquinoline-5,8-quinonc, an inhibitor of cGMP production with little or no effect on cAMP, $10 \mu \mathrm{M}$ (Mulsch et al., 1988); pyrilamine, an $\mathrm{H}_{1}$ receptor antagonist, $10 \mu \mathrm{M}$; and $\mathrm{LY} C \mathrm{CH}$ (3\%). LY83583 was obtained from Calbiochem (La Jolla, CA); all other compounds were from Sigma (St. Louis, MO).

\section{RESULTS}

\section{Neuronal characteristics}

To be included in the studies reported here, a neuron was required to display spontaneous phasic bursting activity (see Fig. 3) and/or to respond to electrical stimulation of the TM with excitatory postsynaptic potentials (EPSPs). These are characteristics that identify an overwhelming majority of SON vasopressin cells (Yamashita et al., 1983; Cobbett et al., 1986; Leng, 1988; Yang and Hatton, 1989, 1994). A total of 139 SON neurons meeting these criteria was recorded and injected with LY. Membrane characteristics of these neurons were similar to those reported in previous studies of this kind by us and others. Membrane potentials were $-58.5 \pm 0.3 \mathrm{mV}$, with action potentials of $65.8 \pm 0.5$ $\mathrm{mV}$ and input resistances of $164 \pm 5 \mathrm{M} \Omega$ (mean $\pm \mathrm{SEM}$ for all measures).

\section{TM stimulation}

Hemisected slices were used in the stimulation studies because the input to the SON from the TM has been found to be both ipsiand contralateral (Weiss et al., 1989). Thus, the hemisection prevented stimulation of the control half of the slice. In this experiment, extracellular electrical stimulation of the TM for 10 min at $10 \mathrm{~Hz}$ was performed on, and LY-injected neurons were recovered from, 13 hemisected slices, one neuron per SON. The unstimulated control halves of these slices yielded 12 injected neurons. Dye coupling was observed in both control and TMstimulated slices (Fig. 2). Plotted in Figure 4 are the numbers of coupled neurons per dye-injected cell for these two conditions. In the control halves, 12 injections yielded 8 single and 8 coupled cells (4 pairs), whereas in slices in which the TM was stimulated for $10 \mathrm{~min}$ at $10 \mathrm{~Hz}, 13$ injections resulted in 4 single and 28 coupled cells, of which there were 4 pairs and 20 cells coupled together in groups of 3-5 neurons. Therefore, not only was there an increased incidence of coupling associated with TM stimulation, but there also was an increase in the number of cells coupled to the injected neuron. This brief TM stimulation produced a greater than threefold increase in the number of coupled neurons per injection (Fig. 4, left). This difference was statistically significant at $p<0.02$.

\section{Blockade by $\mathrm{H}_{1}$ receptor antagonist}

Excitatory effects of TM stimulation or applications of HA on vasopressinergic neurons are via $\mathrm{H}_{1}$ receptor activation (Armstrong and Sladek, 1985; Smith and Armstrong, 1993; Yang and Hatton, 1994; Li and Hatton, 1995). To determine whether the observed stimulation effect on coupling was mediated by this receptor, slices were tested for excitatory synaptic responses of SON cells to TM stimulation, perifused with medium containing the $\mathrm{H}_{1}$ receptor antagonist pyrilamine $(10 \mu \mathrm{M})$, and then the blockade of the synaptic responses was observed (see Fig. 3). Control hemislices werc unstimulated, whereas the other halves were subjected to additional TM stimulation for $10 \mathrm{~min}$ at $10 \mathrm{~Hz}$. The results of these two treatments on neuronal coupling were similar: 9 injections in control and 10 injections in stimulated 


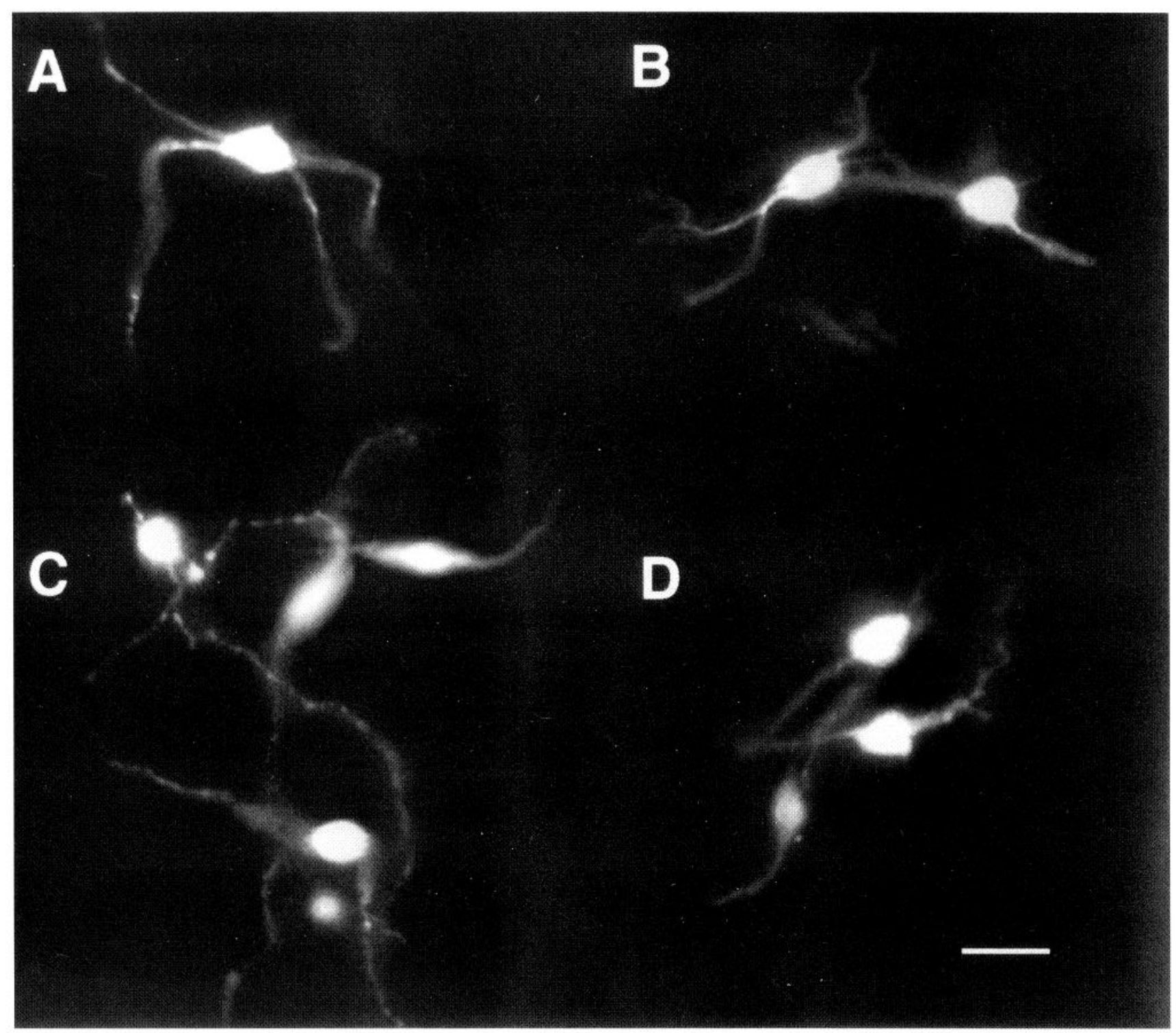

Figure 2. Fluorescence photomicrographs of LY-filled, putative vasopressinergic neurons of the supraoptic nucleus. $A$ and $B$, Dye-filled neurons from control slices. $A$, Single dye-filled neuron. $B$, Coupled pair of neurons that were in the same focal plane. $C$, Montage showing five coupled neurons (not all in the same focal plane) in a slice in which the TM was electrically stimulated for $10 \mathrm{~min}$ at $10 \mathrm{~Hz}$. D, Montage showing coupled triplet of dye-filled neurons in a slice bathed for $30 \mathrm{~min}$ in medium containing $1 \mathrm{~mm}$ 8-bromo-cGMP. In all cases, only one neuron was injected. Note that all coupling is dendrodendritic. Scale bar, $44 \mu \mathrm{m}$.

slices each resulted in 7 coupled neurons and 6 and 7 single cells, respectively. The numbers of coupled neurons per injection (Fig. 4 , right $)$ were not statistically different $(p>0.8)$ from one another or from those of the unstimulated slices incubated in control medium (left bar). $\mathrm{H}_{1}$ receptor blockade seems to have prevented the stimulated increase in the incidence of coupling without affecting basal levels.

\section{Effects of cGMP on coupling}

One mechanism by which the histaminergic input from the TM to the SON might influence the incidence of LY coupling is via cGMP-dependent pathways, because $\mathrm{H}_{1}$ receptors are often linked to guanylate cyclase activation (for review, see Prell and Greene, 1986; Greene, 1994). Incubation of hemislices in 0.5-1.0 mм 8-bromo-cGMP for $30 \mathrm{~min}$ before LY injection resulted in an elevated incidence of coupling compared with that of slices equivalently incubated in control medium. In slices treated with 8-
bromo-cGMP, 19 LY injections produced 6 single dye-filled neurons and 32 coupled cells consisting of 7 coupled pairs and 6 triplets. In contrast, 15 injections into cells in slices kept in control medium yielded 10 single and 10 coupled neurons, the latter all in pairs. This was a 2.5 -fold increase in the number of coupled neurons per injection and was significantly different from control at $p<0.02$ (Fig. 5, left).

\section{Inhibition of cGMP production}

As a further assessment of the possible involvement of cGMP in the observed stimulation-induced increase in coupling incidence, an attempt was made to reduce or inhibit the increased production of cGMP that may occur during histaminergic activation of phasically firing SON neurons. LY injections were made into nine cells in hemislices incubated in control medium and into nine cells in tissue incubated in medium containing the cGMP production inhibitor LY83583 at $10 \mu \mathrm{M}$. This concentration is effective in 


\section{A 1 Phasically firing neuron}

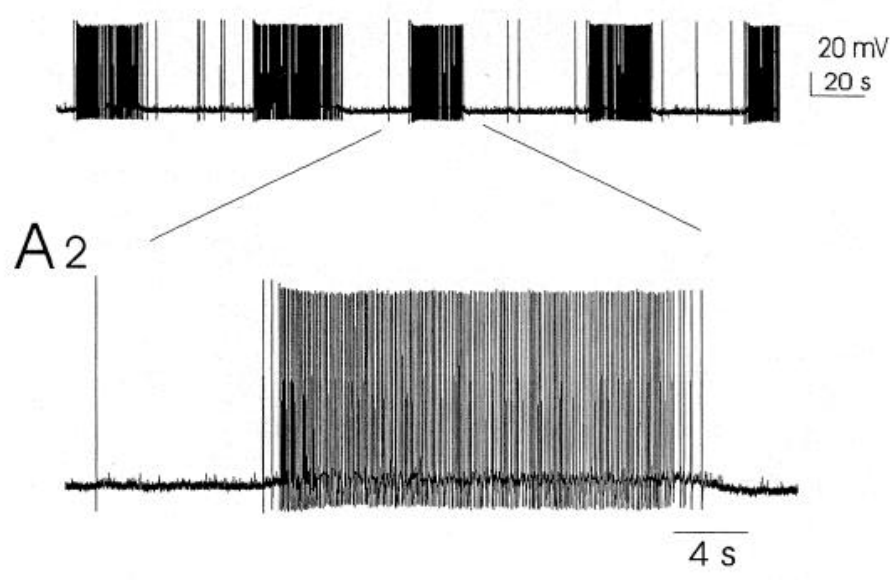

\section{B1 Normal medium}

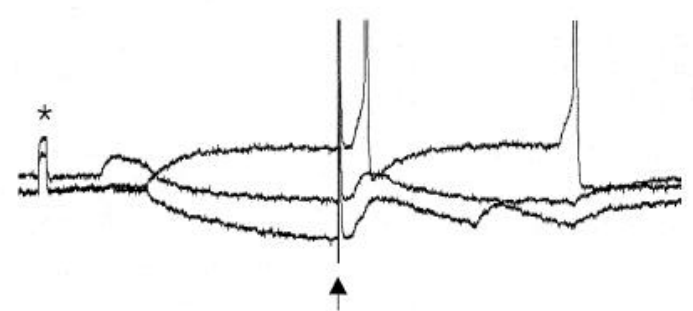

\section{B 2 Pyrilamine $10 \mu \mathrm{M}, 2.5 \mathrm{~min}$}

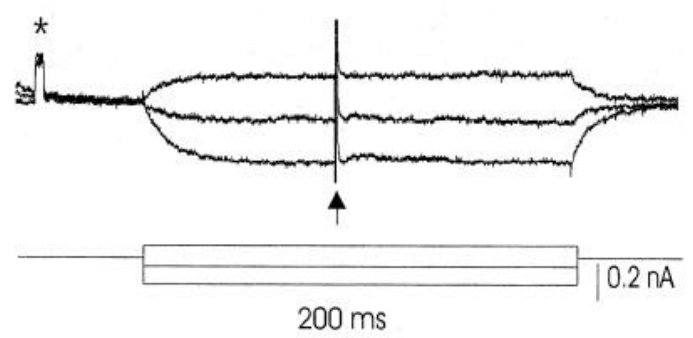

Figure 3. Spontaneous $(A)$ and synaptically evoked $(B)$ activity typical of the supraoptic neurons included in this study. $A 1$, Spontaneously occurring phasic bursting activity. $A 2$, Single burst from $A 1$ at faster sweep speed showing interburst action potential and burst of spikes superimposed on a plateau potential. B1, Voltage records of a putative vasopressinergic neuron responding to stimulation of the TM. Three superimposed sweeps are shown during which the TM was stimulated (arrow). When a small depolarizing current was injected (top), TM stimulation evoked an action potential (truncated here). Hyperpolarizing currents reveal evoked EPSPs (middle and bottom). B2, Same neuron as in B1; bath application of the $\mathrm{H}_{1}$ receptor antagonist pyrilamine $(10 \mu \mathrm{M})$ blocked the EPSPs and action potentials evoked by TM stimulation. Current monitor traces at bottom of $B 2$ also apply to $B 1$. ${ }^{*}$ Calibration pulses of $10 \mathrm{mV}$, $5 \mathrm{msec}$.

preventing the activation of soluble guanylate cyclase and thereby in blocking cGMP production in a variety of tissues including platelets and vascular and kidney cells (Brandt and Conrad, 1991; Fleming et al., 1991; Launay et al., 1994). The TM was then

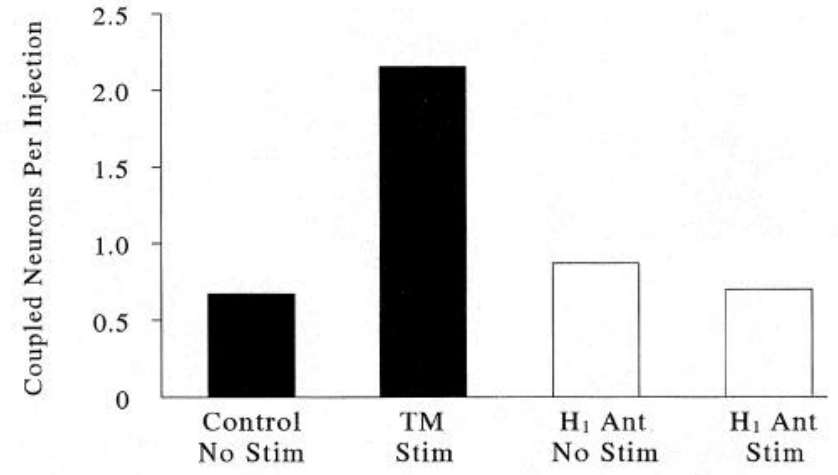

Figure 4. Data from two separate experiments showing the number of coupled neurons per injected cell. Filled bars: hemislices maintained in control medium in which the TM was $(n=13)$ or was not $(n=12)$ electrically stimulated, Control, No Stim, or TM Stim, respectively. Difference was statistically significant at $p<0.02$. Open bars: hemislices treated similarly to those on the left, except that the medium contained $10 \mu \mathrm{M}$ pyrilamine $\left(H_{1} A n t\right) ;$ No Stim $(n=9)$, Stim $(n=10)$. The difference between these two conditions was nonsignificant.

stimulated for $10 \mathrm{~min}$ at $10 \mathrm{~Hz}$ in both sets of hemislices. As in the initial stimulation experiment in this series, TM stimulation of slices in control medium resulted in an enhanced incidence of coupling, the 9 LY injections producing 2 single and 19 coupled dye-filled neurons. As in the TM-stimulated slices of the first experiment, 11 of these 19 cells were in groups of 3 or more coupled neurons. Under conditions in which the medium contained LY83583, however, 9 injections yielded 6 single and 8 coupled cells, the latter consisting of 4 pairs. This 2.4 -fold increase in the number of coupled neurons per injection was significant at $p<0.04$ (Fig. 5, right). Inhibition of the increased production of cGMP that is induced by $\mathrm{H}_{1}$ receptor activation also seemed to interfere with the stimulation-induced increase in the incidence of dye coupling. Because synaptic responses to TM stimulation were observed in both conditions, LY83583 apparently did not interfere with synaptic transmission.

\section{Effects of cAMP on coupling}

Because the SON receives various neurotransmitter inputs, some of which may act by stimulating receptor subtypes linked to adenylate cyclase (e.g., noradrenaline via $\beta$-receptors and dopamine via $\mathrm{D}_{1}$ receptors), the possible effects of cAMP on coupling in this nucleus were of interest. As in the experiments already described, after their initial $3 \mathrm{hr}$ in control medium, hemislices were incubated for 30 min either in control medium or in medium containing $1 \mathrm{~mm}$ 8-bromo-cAMP, after which one phasically firing cell per SON was LY-injected. In control medium, 23 injections yielded 15 single and 16 coupled dye-filled neurons. By contrast, 20 injections into cells bathed in medium containing 8-bromocAMP produced 18 single and only 4 coupled cells ( 2 pairs). This 3.5 -fold decrease in the incidence of coupling was statistically significant at $p<0.02$ (see Fig. 6). Increasing intracellular cAMP in these SON neurons seems to decrease basal levels of coupling.

\section{DISCUSSION}

Our results suggest that $\mathrm{HA}$, released by stimulation of the TM onto vasopressinergic neurons of the SON, enhances the interneuronal transfer of LY. This enhancement seems to be associated with activation of $\mathrm{H}_{1}$ receptors linked to guanylate cyclase, because when either the $\mathrm{H}_{1}$ receptor was blocked or the enzyme was inhibited, stimulation failed to increase the incidence of coupling. Enhanced 


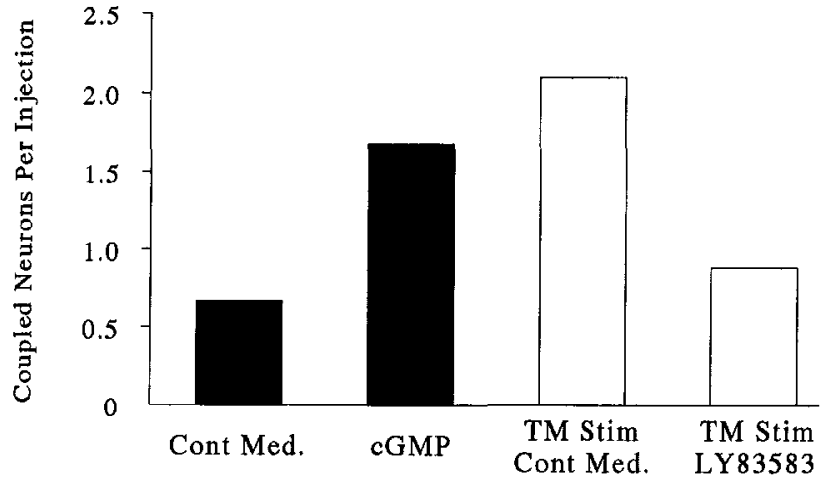

Figure 5. Data from two separate experiments showing the number of coupled neurons per injected cell. Filled bars: hemislices maintained in control medium, Cont Med. $(n=15)$, or in medium containing $0.5-1.0 \mathrm{~mm}$ 8-bromo-cGMP, $c G M P(n=19)$. The difference was significant at $p<$ 0.02. Open hars: hemislices subjected to electrical stimulation of the TM (TM Stim) and maintained in either control medium, Cont Med. $(n=9)$, or medium containing the inhibitor of cGMP production $L Y 83583(n=9)$ at $10 \mu \mathrm{M}$. The difference was significant at $p<0.04$.

coupling induced by raising intracellular cGMP in these neurons suggests that actions of the cGMP-dependent protein kinase are involved. Electrical stimulation of the TM evoked fast EPSPs in the phasically firing neurons studied here (Fig. 3). These responses were blocked by the $\mathrm{H}_{1}$ receptor antagonist pyrilamine, consistent with our previous observations that presynaptically released HA apparently mediates fast neural transmission. These effects of TM stimulation have been characterized more completely in a previous report (Yang and Hatton, 1994), in which it was also found that the evoked EPSPs were not blocked by CNOX or $\mathrm{H}_{2}$ antagonists and therefore were unlikely to be caused by coreleased glutamate or activation of $\mathrm{H}_{2}$ receptors. In the present study, $10 \mathrm{~min}$ of TM stimulation was associated with a threefold increase in interneuronal coupling (Figs. $4,5)$.

It is possible that the coupling increase was simply because of repeated membrane depolarizations. This is unlikely because similar synaptic activation of SON neurons via stimulation of the glutamatergic lateral olfactory tract input was without effect on coupling in males or untreated females (Hatton and Yang, 1990; Modney et al., 1990). Furthermore, increasing cellular cGMP levels (present studies) without synaptic excitation also increased coupling. Finally, TM stimulation during inhibition of guanylate cyclase produced repeated depolarizations but no increase in coupling. Thus, we conclude that the observed enhanced incidence of coupling is attributable to the downstream consequences of $\mathrm{H}_{1}$ receptor activation.

That raising intracellular cAMP had an effect opposite to that obtained with cGMP may signify that these two cyclic nucleotide pathways are involved in phosphorylating different portions of the connexin-32 intracellular domains and that the gating of junctional conductance may be differentially affected by phosphorylation of different amino acid residues. Alternatively, other membrane-associated proteins could be involved as well in one or both of these effects on coupling. Because little is known about the actual influence that phosphorylation of connexin-32 has on factors that would have direct effects on dye transfer, such as unitary conductance or channel opening times, this step in the process is difficult to determine (for review, see Sáez et al., 1993). At present, there are data to indicate that cAMP-dependent phosphorylation of connexin-32 and incrcased junctional conductance between liver cells have a similar time course (Sáez et al., 1990),

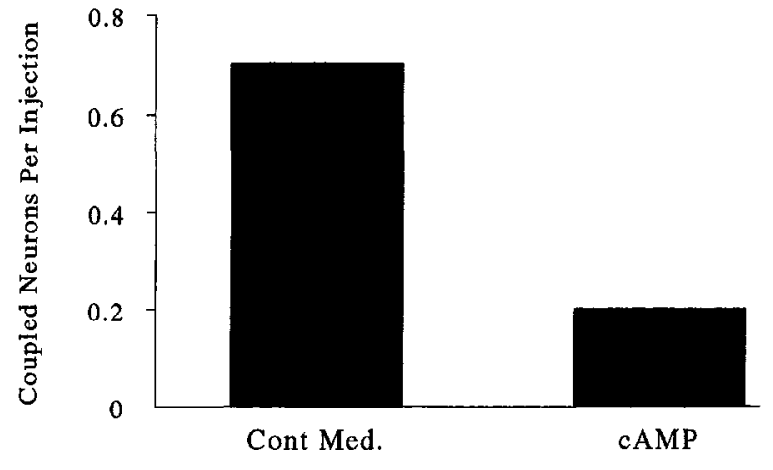

Figure 6. Number of coupled neurons per injected cell in hemislices maintained either in control medium, Cont Med. $(n=23)$, or in medium containing $1 \mathrm{~mm}$ 8-bromo-cAMP, $c A M P(n=20)$. The difference was significant at $p<0.02$. Note expanded ordinate scale compared with Figures 4 and 5 .

but no comparable information is available for cGMP-dependent processes or for neurons in the brain.

To our knowledge, our experiments are the first to show that guanylate cyclase cGMP-dependent mechanisms can modulate coupling among mammalian central neurons or indeed between any cells joined by connexin-32 protein channels. Modulation of coupling through connexin-43-mediated junctions by cGMP has been shown in mammalian cardiac myocytes (Burt and Spray, 1988) and in fish retinal horizontal cells (connexin unknown; DeVries and Schwartz, 1989; Miyachi and Murakami, 1991; Miyachi and Nishikawa, 1994). In all of these cases, the effect of cGMP was to reduce junctional conductance and/or dye coupling. As pointed out by Bennett et al. (1991), influences on junctional conductances tend to vary according to cell type, connexin type, and type of protein kinase involved. Although little is known currently about cGMP actions on junctional conductances in neurons, cAMP is effective in uncoupling both horizontal and amacrine cell types in retinae of several species (Miyachi and Murakami, 1989, 1991; Dong and McReynolds, 1991; Hampson et al., 1994; McMahon and Brown, 1994). The endogenous process underlying the observed uncoupling or decrease in dye transfer is thought to be dopamine acting via $D_{1}$ receptors linked to adenylate cyclase activation. Conversely, dopamine or $\mathrm{D}_{2}$ agonists acting on $\mathrm{D}_{2}$ receptors increase the incidence of coupling among striatal neurons (Onn and Grace, 1994), possibly via the linkage of both $D_{2 L}$ receptors and $D_{2 S}$ receptors to the inhibition of adenylate cyclase (Weiner and Molinoff, 1994). Our present finding that cAMP decreases the incidence of coupling below basal levels in the SON (compare Figs. 5 and 6) is consistent with those of the earlier studies cited above.

Several studies have demonstrated that the number of neurons actually coupled in a network is grossly underestimated by injections and subsequent transfer of LY. Simultaneous injections of LY and either neurobiotin or biocytin into individual neurons in the hypothalamus (Hatton and Yang, 1994), the neocortex (Peinado et al., 1994), and the retina (Vaney, 1991) have shown that there may be 10-200 times more coupled cells than is revealed by LY transfer. It has been estimated that detection of LY coupling requires junctional conductances of $\sim 2 \mathrm{nS}$ (Dermietzel and Spray, 1993), but probably much smaller conductances would be necessary for neurobiotin coupling because it is a smaller, less highly charged molecule. Therefore, LY transfer may represent stronger coupling than neurobiotin transfer within a given network. If so, then the induced increase in the incidence of LY coupling that we 
observed in response to brief stimulation may represent an increase in stronger electrical interactions between the coupled cells. Increased coupling strength would probably be because of channel gating, i.e., number of open channels or increased opening time, rather than to added connexons, because the stimulation, although effective, lasted only $10 \mathrm{~min}$. Changes in junctional conductance between coupled neurons have been modeled and found to have potentially profound influences on such factors as synchrony and firing patterns (Sherman and Rinzel, 1992). It is well established that the amount of vasopressin secreted from terminals in the posterior pituitary is highly dependent on the pattern of firing in that population of neurons (Leng, 1988).

To date, attempts to establish the functional significance of electrotonic coupling for any given set of neurons have been impeded by the difficulties involved in combining determinations of coupling with measures of functional output of the system under study, because most determinations of interneuronal coupling have been carried out using in vitro preparations. Therefore, the currently available data are mostly correlational. In the case of the magnocellular neurons of the SON and paraventricular nucleus, increased coupling incidence has been associated consistently with physiological conditions requiring increased peptide release, i.e., lactation and dehydration (Hatton, 1990). It is noteworthy in this context that intravascular injections of hypertonic saline induce release of $\mathrm{HA}$ into the SON (Akins and Bealer, 1990) and that elevation of hypothalamic HA consistently produces enhanced and protracted release of vasopressin (for review, see Weiss et al., 1989). Increased coupling among groups of vasopressin neurons may aid in coordinating such hormonal responses. Of interest in determining the functional significance of electrotonic interactions between neurons will be those factors that control or modulate the incidence and/or the strength of coupling. In addition to the aforementioned actions of dopamine, it has been shown that gonadal steroids, for example, are capable of up- or downregulation of coupling incidence in the hypothalamic paraventricular and SON neurons, depending on which steroid is manipulated (Cobbett et al., 1987; Hatton et al., 1992); that testosterone modulates the occurrence of gap junctions in the nucleus of the bulbocavernosus of the spinal cord in males (Matsumoto et al., 1988); and that brief activation of glutamatergic synaptic inputs to SON neurons increases neuronal coupling under some physiological conditions but not under others (Hatton and Yang, 1990; Modney et al., 1990). Our results extend this knowledge to include modulatory effects of synaptically released HA and cyclic nucleotides.

\section{Technical considerations}

Phasic bursting firing patterns are characteristic of activated vasopressin neurons in the rat (Yamashita et al., 1983; Cobbett et al., 1986), but occasionally such patterns have been observed in identified oxytocin cells (Brimble and Dyball, 1977; Armstrong et al., 1994; Moos and Ingram, 1995). It is now known that the existence of these phasic firing patterns is dependent on the complement of intracellular calbindin- $\mathrm{D}_{28 \mathrm{k}}$ of the neuron (Li et al., 1995) and that both cell types are capable of generating phasic bursting activity. The added criterion that was used in the present study, excitatory responses to TM stimulation combined with phasic firing, makes it likely that all neurons included in our data samples were indeed vasopressinergic. That all of the neurons coupled to the injected cells were vasopressinergic also is likely, because coupling among neurons in this system is consistently homotypic with respect to peptide type (Cobbett et al., 1985; Hatton et al., 1987; Yang and Hatton, 1987).

\section{REFERENCES}

Akins VF, Bealer SL (1990) Brain histamine regulates pressor responses to peripheral hyperosmolality. Am J Physiol 259:R507-R513.

Andrew RD, MacVicar BA, Dudek FE, Hatton GI (1981) Dye transfer through gap junctions between neuroendocrine cells of the rat hypothalamus. Science 211:1187-1189.

Armstrong WE, Sladek CD (1985) Evidence for excitatory actions of histamine on supraoptic neurons in vitro: mediation by an $\mathrm{H}_{1}$-type receptor. Neuroscience 16:307-322.

Armstrong WE, Smith BN, Tian M (1994) Electrophysiological characteristics of immunocytochemically identified rat oxytocin and vasopressin neurones in vitro. J Physiol (Lond) 475:115-128.

Baker R, Llinas R (1971) Electrotonic coupling between neurones in the rat mesencephalic nucleus. J Physiol (Lond) 212:45-63.

Bennett MVL, Barrio LC, Bargiello TA, Spray DC, Hertzberg E, Sáez JC (1991) Gap junctions: new tools, new answers, new questions. Neuron 6:305-320.

Brandt MA, Conrad KP (1991) In vivo and in vitro studies of a putative inhibitor of cyclic guanosine $3^{\prime}, 5^{\prime}$-monophosphate production. Proc Soc Exp Biol Med 196:30-35.

Brimble MJ, Dyball REJ (1977) Characterization of the responses of oxytocin and vasopressin secreting neurones in the supraoptic nucleus to osmotic stimulation. J Physiol (Lond) 271:253-271.

Burt JM, Spray DC (1988) Ionotropic agents modulate gap junctional conductance between cardiac myocytes. Am J Physiol 254:H1205-H1210.

Cobbett P, Hatton GI (1984) Dye coupling in hypothalamic slices: dependence on in vivo hydration state and osmolity of incubation medium. J Neurosci 4:3034-3038.

Cobbett P, Smithson KG, Hatton GI (1985) Dye coupled magnocellular peptidergic neurons of the rat paraventricular nucleus show homotypic immunorcactivity. Ncuroscicnce 16:885-895.

Cobbett P, Smithson KG, Hatton GI (1986) Immunoreactivity to vasopressin- but not oxytocin-associated neurophysin antiserum in phasic neurons of rat paraventricular nucleus. Brain Res 362:7-16.

Cobbett P, Yang QZ, Hatton GI (1987) Incidence of dye coupling among magnocellular paraventricular neurons in male rats is testosterone de pendent. Brain Res Bull 365-370.

Dermietzel R, Spray DC (1993) Gap junctions in the brain: where, what type, how many and why? Trends Neurosci 16:186-192.

DeVries SH, Schwartz EA (1989) Modulation of an electrical synapse between solitary pairs of catfish horizontal cells by dopamine and second messengers. J Physiol (Lond) 414:351-375.

De Zeeuw CI, Hertzberg EL, Mugnaini E (1995) The dendritic lamellar body: a new neuronal organelle putatively associated with dendrodendritic gap junctions. J Ncurosci 15:1587-1604.

Dong C-J, McReynolds JS (1991) The relationship between light, dopamine release and horizontal cell coupling in the mudpuppy retina. $\mathbf{J}$ Physiol (Lond) 440:291-309.

Fleming I, Julou-Schaeffer G, Gray GA, Parrat JR, Stoclet J-C (1991) Evidence that an L-arginine/nitric oxide dependent elevation of tissue cyclic GMP content is involved in depression of vascular reactivity by endotoxin. Br J Pharmacol 103:1047-1052.

Grace AA, Bunney BS (1983) Intracellular and extracellular electrophysiology of nigral dopaminergic neurons. 3. Evidence for electrotonic coupling. Neuroscience 10:333-348.

Greene JP (1994) Histamine. In: Basic neurochemistry (Siegel GJ, Agranoff BW, Albers RW, Molinoff PB, eds), pp 309-319. New York: Raven.

Gutnick MJ, Prince DA (1981) Dye coupling and possible electrotonic coupling in guinea pig neocortical slices. Science 211:67-70.

Haas HL, Schaerer B, Vosmansky M (1979) A simple perfusion chamber for the study of nervous tissue slices in vitro. J Neurosci Methods 1:323-325.

Hampson ECGM, Weiler R, Vaney DI (1994) pH-gated dopaminergic modulation of horizontal cell gap junctions in mammalian retina. Proc R Soc Lond [Biol] 255:67-72.

Hatton GI (1990) Emerging concepts of structure-function dynamics in adult brain: the hypothalamo-neurohypophysial system. Prog Neurobiol 34:437-504.

Hatton GI, Doran AD, Salm AK, Tweedle CD (1980) Brain slice preparation: hypothalamus. Brain Res Bull 5:405-414. 
Hatton GI, Micevych PE (1992) Connexin $32 \mathrm{mRNA}$ levels in the supraoptic nucleus prior to and during lactation. Soc Neurosci Abstr 18:417.

Hatton GI, Yang QZ (1990) Activation of excitatory amino acid inputs to supraoplic neurons. I. Induced increases in dye coupling in lactating, but not virgin or male rats. Brain Res 513:264-269.

Hatton GI, Yang QZ (1994) Incidence of neuronal coupling in supraoptic nuclei of virgin and lactating rats: estimation by neurobiotin and Lucifer yellow. Brain Res 650:63-69.

Hatton GI, Yang QZ, Cobbett P (1987) Dye coupling among immunocytochemically identified neurons in the supraoptic nucleus: increased incidence in the lactating rat. Neuroscience 21:923-930.

Hatton GI, Yang QZ, Koran LE (1992) Effects of ovariectomy and estrogen replacement on dye coupling among rat supraoptic nucleus neurons. Brain Res 572:291-295.

Inagaki $\mathrm{N}$, Yamatodani $\mathrm{A}$, Ando-Yamamoto $\mathrm{M}$, Tohyama $\mathrm{M}$, Watanabe $T$, Wada $H$ (1988) Organization of histaminergic fibers in the rat brain. J Comp Neurol 273:283-300.

Launay J-M, Bondoux D, Oset-Gasque M-J, Emami S, Mutel V, Haimart M, Gespach C (1994) Increase of human platelet serotonin uptake by atypical histamine receptors. Am J Physiol 266:R526-R536.

Leng G (1988) Pulsatility in neuroendocrine systems. Boca Raton, FL: CRC.

Li Z-H, Decavel C, Hatton GI (1995) Calbindin-D ${ }_{28 k}$ : role in determining intrinsically generated firing patterns in rat supraoptic neurones. $\mathbf{J}$ Physiol (Lond) 488:601-608.

Li Z-H, Hatton GI (1995) Histamine-induced prolonged depolarization in rat supraoptic neurons: G-protein mediated $\mathrm{Ca}^{2+}$-independent suppression of $\mathrm{K}^{+}$leakage conductance. Neuroscience, in press.

Llinas R, Baker R, Sotelo C (1974) Electrotonic coupling between neurons in cat inferior olive. $\mathrm{J}$ Neurophysiol 37:560-571.

MacVicar BA, Dudek FE (1981) Electrotonic coupling between pyramidal cells: a direct demonstration in rat hippocampal slices. Science 213:782-785.

MacVicar BA, Dudek FE (1982) Electrotonic coupling between granule cells of rat dentate gyrus: physiological and anatomical evidence. $J$ Neurophysiol 47:579-592

Matsumoto A, Arnold AP, Zampighi GA, Micevych PE (1988) Androgenic regulation of gap junctions between motoneurons in the rat spinal cord. J Neurosci 8:4177-4183.

McMahon DG, Brown DR (1994) Modulation of gap-junction channel gating at zebrafish retinal electrical synapses. J Neurophysiol 72:2257-2268.

Micevych PE, Abelson L (1991) Distribulion of mRNAs coding for liver and heart gap junction proteins in the rat central nervous system. $J$ Comp Neurol 305:96-118.

Miyachi E-I, Murakami M (1989) Decoupling of horizontal cells in carp and turtle retinae by intracellular injection of cyclic AMP. J Physiol (Lond) 419:213-224.

Miyachi E-I, Murakami M (1991) Synaptic inputs to turtle horizontal cells analyzed after blocking of gap junctions by intracellular injection of cyclic nucleotides. Vision Res 31:631-635.

Miyachi E-I, Nishikawa C (1994) Blocking effect of L-arginine on retinal gap junctions by activating guanylate cyclase via generation of nitric oxide. Biog Amines 10:459-464.

Modney BK, Yang QZ, Hatton GI (1990) Activation of excitatory amino acid inputs to supraoptic neurons. II. Increased dye coupling in maternally behaving virgin rats. Brain Res 513:270-273.

Moos FC, Ingram CD (1995) Electrical recordings of magnocellular supraoptic and paraventricular neuron displaying both oxytocin- and vasopressin-related activity. Brain Res 669:309-314.

Mulsch A, Busse R, Liebau S, Forstermann U (1988) LY 83583 interferes with the release of endothelium-derived relaxing factor and inhibits soluble guanylate cyclase. J Pharmacol Exp Ther 247:283-288.
Nagy JI, Yamamoto T, Shiosaka S, Dewar KM, Whittaker ME, Hertzberg EL (1988). Immunohistochemical localization of gap junction protein on rats CNS: a preliminary account. In: Gap junctions (Hertzberg EL, Johnson RG, eds), pp 375-389. New York: Liss.

O'Donnell P, Grace AA (1993) Dopaminergic modulation of dye coupling between neurons in the core and shell regions of the nucleus accumbens. J Neurosci 13:3456-3471.

Onn S-P, Grace AA (1994) Dye coupling between rat striatal neurons recorded in vivo: compartmental organization and modulation by dopamine. J Neurophysiol 71:1917-1934.

Panula P, Pirvola U, Auvinen S, Airaksinen MS (1989) Histamine-immunoreactive nerve fibers in the rat brain. Neuroscience 28:585-610.

Peinado A, Yuste R, Katz LC (1994) Extensive dye coupling between rat neocortical neurons during the period of circuit formation. Neuron 10:103-114.

Phalen KD, Twery MJ, Gallagher JP (1993) Morphological and electrophysiological evidence for electrotonic coupling of rat dorsal septal nucleus neurons in vitro. Synapse 13:39-49.

Prell GD, Greene JP (1986) Histamine as a neuroregulator. Annu Rev Neurosci 9:209-254.

Sáez JC, Berthoud VM, Moreno AP, Spray DC (1993) Gap junctions. In: Advances in second messenger and phosphoprotein research (Shenoliker S, Nairn AC, eds), pp 163-198. New York: Raven.

Sáez JC, Nairn AC, Czernik AJ (1990) Phosphorylation of connexin 32, a hepatocyte gap-junction protein, by cAMP-dependent protein kinase, protein kinase $\mathrm{C}$ and $\mathrm{Ca}^{2+} /$ calmodulin-dependent protein kinase II. Eur J Biol Chem 192:263-273.

Sherman A, Rinzel J (1992) Rhymogenic effects of weak electrotonic coupling in neuronal models. Proc Natl Acad Sci USA 89:2471-2474.

Smith BN, Armstrong WE (1993) Histamine enhances the depolarizing afterpotential of immunocytochemically identified vasopressin neurons in the rat supraoptic nucleus via $\mathrm{H}_{1}$-receptor activation. Neuroscience 53:855-864.

Stewart WW (1978) Function connections between cells as revealed by dye-coupling with a highly fluorescent naphthalimide tracer. Cel 14:741-759.

Travagli RA, Wessendorf M, Dunwiddie TV, Williams JT (1994) The opioid induced current in rat locus coeruleus neurons: electrotonic considerations. Soc Neurosci Abstr 20:1734

Vaney DI (1991) Many diverse types of retinal neurons show tracer coupling when injected with biocytin or neurobiotin. Neurosci Lett 125:187-190.

Vaney DI (1994) Patterns of neuronal coupling in the retina. Prog Ret Eye Res 13:302-355.

Weiner N, Molinoff PB (1994) Catecholamines. In; Basic neurochemistry (Siegel GJ, Agranoff BW, Albers RW, Molinoff PB, eds), pp 261-281. New York: Raven.

Weiss ML, Yang QZ, Hatton GI (1989) Magnocellular tuberomammillary nucleus input to the supraoptic nucleus in the rat: anatomical and in vitro electrophysiological investigations. Neuroscience 31:299-311.

Yamashita H, Inenaga K, Kawata M, Sano Y (1983) Phasically firing neurons in the supraoptic nucleus of the rat hypothalamus: immunocytochemical and electrophysiological studies. Neurosci Lett 37:87-92.

Yang QZ, Hatton GI (1987) Dye coupling among supraoptic nucleus neurons with and without dendritic damage: differential incidence in nursing mother and virgin rats. Brain Res Bull 19:559-565.

Yang QZ, Hatton GI (1988) Direct evidence for electrical coupling among rat supraoptic nucleus neurons. Brain Res 463:47-56.

Yang QZ, Hatton GI (1989) Histamine and histaminergic inputs: responses of rat supraoptic nucleus neurons recorded intracellularly in hypothalamic slices. Biomed Res 10:135-144.

Yang QZ, Hatton GI (1994) Histamine mediates fast synaptic inhibition of rat supraoptic oxytocin neurons via chloride conductance activation. Neuroscience 61:955-964. 